\title{
A Future Map of Mathematics Education Research in View of the 2030 Vision
}

\author{
Aeshah J. Aljohani (Corresponding author) \\ Ministry of Education, Kingdom of Saudi Arabia \\ E-mail: a.alalwani@hotmail.com
}

\author{
Mohammed A. Alnatheer \\ Faculty of Education, King Saud University, Kingdom of Saudi Arabia \\ E-mail: alnatheer@ksa.edu.sa
}

Received: May 9, 2020 Accepted: June 11, 2020 Published: June 22, 2020

doi:10.5296/jei.v6i1.17013 URL: https://doi.org/10.5296/jei.v6i1.17013

\begin{abstract}
This paper discusses the reality of mathematics education researchers in terms of: methodology, samples, tools, and the thematic trends. It also sets a model for building a proposed future map for mathematics education research in view of the pillars of Vision 2030. The study used the descriptive analytical method, and the sample consisted of reviewing 51 researches in mathematics education. The results indicate that the majority of mathematics education research was descriptive. The research sample was also focused on students, and the method of simple random sampling. The majority of researches relied on one tool for the researchers' design, and the tests were the most used. Researches also focused on the primary stage. The largest percentage of mathematics education, research aimed to measure the impact and effectiveness of teaching aids and techniques. The research provided a model for a research map that guides the course of future research in the field of mathematics education from the perspective of the goals and objectives of the Vision 2030.
\end{abstract}

Keywords: Research map, Vision 2030, Mathematics education research

\section{Introduction}

Educational studies are an important field of scientific research. It seeks to identify educational problems in the society, prioritize, analyze them scientifically, and develop scientific solutions for their treatment (Ibrahim \& Abdel-Majid, 2006). 
With increasing interest in educational research and increasing the number of institutions, periodicals and conferences concerned with it, it still suffers from many problems and the most important problems confirmed by the studies:

- The weakness of linking educational research to the comprehensive development plans in our Arab societies, and the lack of interest of the implementing agencies in the results of research and studies.

- Absence of educational research policies and clear research plans.

- Scattering research efforts, lack of seriousness, and create a sense of non-necessity.

- Lack of coordination in research between institutions, but within the same institution sometimes. Through a repetition of research in terms of content and objectives.

- The absence of research maps through which graduate students work has led to the prolongation of the registration period for degrees, and thus the period of obtaining it, on the one hand. It has also made the subjects and recorded research seem isolated islands and have no real value to science and society.

Al-Baadi (1989) pointed to the low level of quality of educational research prepared by the researchers, the lack of theoretical and applied importance of this research and its focus on some type of research at the expense of other species. Al-Salem (2003) pointed out that most of the research projects submitted by postgraduate students do not deal with contemporary scientific, and social issues, as they deal with theoretical and historical issues that have nothing to do with reality and may not contribute to promoting the ambitious development projects currently being sought by the state.

To solve these problems, we need scientific research emanating from the classification, planning and systematic guidance of its areas, and priorities enriches the research process and unites its efforts and directs it to the requirements of the research areas on the one hand and the requirements of sustainable development and state plans on the other. This paper was discussed in an attempt to draw up a proposed vision for a proposed future map for research in mathematics education in Saudi Arabia under the foundations of Vision 2030.

Harb (2013) refers to the absence of research policy for educational research. There are no clear criteria to guide educational research or employ resources to serve the educational issues of research priority, which led to the absence of the research map in the educational departments of the faculties of education. Azab (2013) points to a number of obstacles and problems facing educational research, including the absence of a clear policy in which educational research is conducted, the lack of coordination between educational research institutions, and the lack of linking the research effort to the goals of comprehensive development.

Al-Salem (2003) believes that one of the most important impacts of postgraduate programs in Saudi universities is a clear repetition of the subjects of the approved and recorded messages due to the lack of clarity regarding the subjects that were approved and the absence of a biographical control of the messages at the local level. Researchers have difficulty finding the 
right subjects for their messages, resulting in a repetition of a number of topics already studied (Alshaya, 2007). The Center for Research Excellence in the Development of Science and Mathematics Education at King Saud University (1430H) stressed the need to prioritize scientific research.

The study of Al-Muatham (2007) confirmed the lack of research in the teaching of mathematics as a research map that guides researchers in this field and starts from an adequate and accurate survey of trends in mathematics education in Saudi Arabia.

It is clear that a research proposal is needed to guide future research in the field of mathematics education from the perspective of the goals and objectives of the Vision 2030.

The study problem is summarized in the following questions:

(1) What is the reality of mathematics education research in the Kingdom of Saudi Arabia during the period (2014-2018) in terms of: research methodology, sampling (type, method of selection), tools (number, type, source)?

(2) What are the objective orientations of mathematics education research in the Kingdom of Saudi Arabia during the period (2014-2018)?

(3) What is the proposed scenario for a research map that will guide future research in the field of mathematics education in view of the foundations of Vision 2030 ?

\section{Literature Review}

\subsection{Research Map}

Maps are used as effective scientific tools in the fields of developmental, economic, social and educational planning at the local and regional levels and vary according to the target and the desired purpose, including school, demographic, economic and other maps. In the field of education, educational maps work to diagnose the educational reality from its various dimensions internally and externally to reveal the strengths and weaknesses in this reality according to certain criteria and indicators (Amer, 2007).

The educational map is defined as "a set of maps prepared for the purpose of diagnosing the educational reality from its various dimensions within and outside the school, in order to reveal the strengths and weaknesses of this reality according to the criteria and certain influences" (Abdul Hay, 2006). The educational map represents a program that translates the planning process into clear and precise stages and steps that are specific to specific times and places in order to achieve the desired educational goals in a scientific way, including the study of the educational reality and its diagnosis and a future vision of what educational services should be in light of the available resources and capabilities according to the requirements of the environment. The importance of educational maps lies in their ability to provide educational data and data that serve the planners and educational policies to achieve consistency and integration between educational activities and to determine the future expectations of education in the light of the current situation and what future educational development requires in providing solutions for the future and directing education in a balanced and balanced 


\section{Macrothink}

direction, with the needs of social and economic development (Amer, 2007).

The concept of the research map is linked to the concept of educational maps where there is a minimum of common elements between the research map and the educational map. The research map is one of the types of educational maps used to direct and rationalize scientific research. It represents the future development of education and is drawn up and formulated within the framework of the development plan. Al-Astadh and Al-Hajjar (2005) defined it as a "realistic and future vision for educational research that clarifies the qualitative and quantitative aspects related to the extent to which these researches conform to the requirements of development in society and meet its needs".

In view of the literature that dealt with the areas of research in the teaching and learning of mathematics, there are many previous efforts and attempts by specialists in the field of mathematics education (international and Arably) to identify areas of research in mathematics education based on long experience in the field of educational research, such as Brophy (1987), Where he presented a range of areas that he believes need to be studied and studied in the future. The most important of these areas: linking curriculum research to research psychology in mathematics, in so-called psychological mathematics research, focus on limited polarity units, teaching to stimulate motivation, activate the mathematical thinking. The Center for Research Excellence in the Development of Science and Mathematics Education at King Saud University (2009) adopted an exploratory study to identify "research priorities in science and mathematics education in the Kingdom of Saudi Arabia" and aims to identify areas of research in science education and general and secondary mathematics, The study was chosen by a group of experts in the teaching of mathematics, and the application of the method of Delphi on two rounds, the first round aims to identify the views of experts on the subject of the study, and the second round to reach an agreement between the views of experts and the results of the study by identifying eight major research areas:

(1) Learning mathematics.

(2) Teaching Mathematics.

(3) Math curriculum, mathematics education policies and standards.

(4) Evaluation in Mathematics Education.

(5) Preparing and qualifying mathematics teachers.

(6) Cultural and social diversity and gender differences in mathematics education.

(7) History, philosophy and nature of mathematics.

(8) Education techniques.

Mina (2002 AD) also identified a number of postulates that he believes represent the basis on which future mathematics and educational research will be built. The most important of these are:

- Mathematics is an existing field of knowledge. Hence, it cannot be viewed in isolation from 
contemporary and future trends in knowledge science.

- Education must keep pace with the existing knowledge developments by addressing knowledge in an integrated manner and focusing on solving problems and avoiding the idea of simplification or reduction. This will only be achieved by following unconventional methods of teaching (self-learning, group work, dialogue, brainstorming...) and bringing about fundamental changes in methods and tools of evaluation.

- The need to develop new mathematics to represent "consistency behavior", such as chaos theory and disaster theory.

- Thought is not governed by logic, but rather the closest to health is that logic is governed by thought. This resulted in looking at induction and reasoning as integrated methods of thinking.

- Looking ahead is an essential part of knowledge.

- Education of the future is supposed to be built on the basis of multiple intelligences, which requires a wide range of choices in the content of the study, and flexibility in its organization.

Abrahiem's (1984) study is one of the studies aimed at determining trends in scientific research in the field of teaching mathematics. The study aimed to determine the trends of scientific research in the field of teaching mathematics in the basic education stage in Egypt. The study sample consisted of (61) researches from mathematics education research, which were classified into (16) different fields. The results of the study were as follows:

- Multiple areas of research regarding the mathematics of basic education.

- The absence of an organized research map for the efforts of researchers. The research is carried out according to the researcher's own efforts in choosing his subject without coordinating or linking with other researchers or without a general research map pertaining to the basic education stage.

In the field of setting priorities and directions of research in the field of teaching and learning mathematics in the Kingdom of Saudi Arabia came the study (Al-Muatham, 2007), which aims to identify the research trends (methodologies and objective) for the research of mathematics education in postgraduate studies in the universities of Saudi Arabia. The most important findings of the study all studies in the teaching of applied mathematics, most of them quantitative, focused on the two descriptive, and then experimental, methodologies were the most descriptive method used.

Khalifa's study (2002) aimed to identify the trends of educational research for teachers of mathematics education, the path of the educational renewal movement of these researches in Egypt, and the role of those researches in the development of mathematics education. The sample of the study was limited to the research of the professor of mathematics education in Egypt (Professor Degree), which is (13) professors, and included all the research, articles and books that were made available to the researcher and (245) research and writing and writing. The researcher concluded that: The majority of these researches were individual. And that the largest proportion is based on the experimental approach in the design of the control and 
experimental groups or the tribal and remote test.

Al-Shaya's (2007) study aims to know the orientations and characteristics of a master's thesis in the approved scientific education in the Faculty of Education, King Saud University. The researcher analyzed the content (94) research, and the study tool in which the analysis card prepared by the researcher. The study concluded with a number of results: regarding the study orientation:

Courses: Science courses at the secondary level (28.8\%) and intermediate (19.1\%) are the most targeted stages of education.

General objectives of science education: The acquisition of scientific knowledge gained the most attention (54.3\%), the acquisition of practical skills $(22.3 \%)$, the development of scientific trends, tendencies and interests $(9.6 \%)$. while no message was concerned about the importance of science and scientists' efforts.

The objectives of science education: Most of the messages focused on the purpose of scientific knowledge (60.6\%), followed by the scientific method $(38.3 \%)$, personal needs $(25.8 \%)$, the purpose of community issues $(10.6 \%)$, The purpose of directing students to future occupations available in the fields of science are not covered by any message.

Al-Al-Balawi's study (2010) aims at identifying the main and secondary research areas and priorities in the teaching and learning of mathematics in Saudi Arabia. The study results in limiting research fields in teaching and learning mathematics in eight main areas:

- Learning mathematics: This includes research on how to learn mathematics and the conceptual development of mathematics learners and the intellectual growth associated with learning mathematics as well as their attitudes, motivation and beliefs towards mathematics and learning, and also includes research on the learning environment and teaching mathematics of life and practice, the effectiveness of these methods.

- Teaching Mathematics: This includes research on the general teaching methods and applications in the field of teaching mathematics, as well as research on the methods of teaching specific subjects of mathematics, teaching and learning in mathematics laboratories, and the attitudes of mathematics teachers and their motivation towards mathematics and teaching.

- Math curriculum and mathematics education policies and standards: This section includes research on the curricula of mathematics in terms of history, construction and development, as well as in terms of integration with science curricula and their overlap with other school curricula, and also includes this policy and standards of mathematics education.

- Evaluation in the teaching of mathematics: This includes research on the evaluation of the content of mathematics books and evaluate the efficiency of mathematics teachers and the evaluation of systems and programs related to teaching mathematics as well as the evaluation of research in mathematics education. 
- Preparation and qualification of mathematics teachers: This includes research on the preparation of the teacher for service and professional development during and includes standards and policies for the rehabilitation of teachers of mathematics and their choice of service.

- Cultural and social diversity and gender differences in mathematics education. This includes research on the teaching of mathematics and the cultural, social and economic differences of learners. It also includes research on gender differences in learning mathematics, as well as teaching and teaching mathematics to gifted students with special needs and low achievers.

- History, philosophy and nature of mathematics: This includes research on the philosophy, nature and history of mathematics and learning, and also includes research on the ethics of science and its principles related to the teaching of mathematics.

- Education techniques: This includes research on the integration of teaching techniques with the teaching and learning of mathematics and the evaluation of learning mathematics and includes research on the use of technology in the laboratories of mathematics and research on e-learning and distance learning.

The study of Al-Maatham (2013) also aimed to analyze the scientific production in mathematics education published in Gulf magazines to identify the methodological and objective approaches. She followed the content analysis approach and used a card to analyze 164 rigorous mathematics education papers published in 30 Gulf Court magazines. And concluded a number of results, the most important of which:

In the field of methodological trends: Most of the scientific production went towards applied research. Applied research focused on the quantitative approach, especially the descriptive and experimental methods. The survey method was the most descriptive, and then associative, method. This production targeted human societies; students were the most targeted groups of human society, then teachers. The research that used one tool is similar to the one with its many tools. The largest trend was the share of achievement tests, and then the measures of all kinds. The rest of the instruments, such as the interview and the analysis and observation card, did not receive sufficient attention in that production.

In the field of objective orientations: the scientific production focused on the study of general and postgraduate education. The primary stage (in both lower and higher branches) was the most targeted, then intermediate, level of general education. Most of the scientific production focused on studying the variables of the learner, then the curriculum, and decreasing his interest in the teacher and the learning environment. The curriculum variables were concerned with the study of teaching and learning methods, educational methods and teaching techniques, mathematical content, and less attention to textbooks, activities and goals. He focused in the branches of content on the study of numbers and processes, and then engineering and algebra, and in its operations to solve the mathematical issue. And was interested in studying the cognitive aspects of the learner, and then emotional, and less targeting of the technical aspects. 


\subsection{Future Features of Education under the Vision of Saudi Arabia 2030}

The Kingdom has adopted a comprehensive planning approach since its inception with the five-year plans, as it is the ideal framework for guiding development paths towards coherent and integrated goals. This development planning took into account the balance between economic growth and the preservation of great values and legacies. The successive development plans were adopted according to a scientific approach, which allowed the rational use of national resources, which enabled the Kingdom to achieve significant developments, reflected in the great rise witnessed by various indicators of economic and social development.

The final document entitled "Transforming our world: the sustainable development map for 2030 was adopted at the United Nations Summit held at United Nations Headquarters from 25 to 27 September 2015, which includes 17 goals, 169 goals, (229) indicators. The aspirations of the Kingdom to realize the goals of the development plans, including the Vision 2030 to promote the community, are reflected in the vision: "Our ambition is to build a more prosperous country where every citizen has a wish and the future of our homeland. Opportunities for all". The fourth objective of the objectives of sustainable development of education, which consists of seven goals, and three means of implementation, provides: "Ensuring a fair and inclusive education for all and enhancing lifelong learning opportunities for all" (Al-Ama'i, 2018). In order to build the capacity and capabilities required to achieve the ambitious goals of the vision of Saudi Arabia 2030, the need to launch the National Transformation Program as an executive vision program was launched at 24 government agencies based on the economic and development sectors. And the establishment of the infrastructure is necessary to achieve the vision and to accommodate its ambitions and requirements.

The participation of the Ministry of Education within the State sectors in the construction of the National Transition 2020 program, where challenges to education, building general education goals and performance indicators, as well as building educational and educational initiatives for the national transformation program, were monitored.

General objectives of the Ministry of Education in building the National Transition Program 2020:

- Ensure fair and inclusive education for all and promote lifelong learning opportunities for all.

- Improve the recruitment, rehabilitation and development of teachers.

- Improving the educational environment that stimulates creativity and innovation.

- Improving the financial efficiency of the education sector.

- Development of curricula and methods of education and evaluation.

- Enhance the values and skills of students.

- Strengthen the capacity of the education and training system to meet the requirements of development and labor market needs. 
- Increasing participation of the private and private sector in education and training.

Education is one of the pillars of an important knowledge economy, and the role of education is central to building a knowledge economy in any society. The vision of the Kingdom of Saudi Arabia 2030 and the National Transition Program 2020 have confirmed the great role of Saudi universities in the coming period. The vision and the program confirmed the role of universities in qualifying the national human resources qualitatively qualifies for the needs of the next stage to meet the needs of the labor market and the requirements of sustainable development. Scientific research has become an important knowledge commodity that countries compete to spend on. They contribute to the comprehensive and sustainable development of societies if research results are translated into a productive commodity that can be marketed and invested through the development of technology incubators and business incubators that transform ideas into products they are marketed and invested (Al-Khalifa, 2015).

Moreover, scientific research supports the important roles of the scientific research and development of researchers in universities, which requires attention to the creation of the knowledge environment of the academic communities through the establishment of scientific concepts, research skills and ethical standards to achieve the highest quality in the research content to meet the requirements of transition to the knowledge society and economy (Al-Salahi, 2017).

Based on the above, the current research focused on the future features of education in accordance with the goals of the vision of Saudi Arabia 2030, which represents a roadmap for a new phase in the history of the Kingdom. The mathematics education system and its inputs, outputs and processes are primarily concerned with achieving the goals and policies of development plans to drive the economy by bridging the gap between the outputs of education and the demands of the labor market.

\section{Method}

The study used the descriptive analytical approach, which is the type of research that aims to describe the phenomenon studied in terms of nature and degree of existence only, which is defined as "a method of research aimed at the quantitative and systematic description of the content and thus reach the researcher to issue a certain ruling on the predominant trend in a particular case" (Assaf, 2010). To achieve the aims of the study, the study sample was chosen from (51) researches as follows:

- Mathematics education researches which was deposited during the period (2014-2018) in the King Fahd National Library with a total of (17) researches.

- Mathematics education researches which was published in the Journal of the Saudi Society for Educational and Psychological Sciences (Justin) starting from the number (44 on March 2014 ) to the number (62 on September 2018) and its number (16) research.

- Mathematics education researches which was published in Taibah University Journal for Educational Sciences, which was carried out in the Kingdom of Saudi Arabia, which was published in the beginning of volume (9) No. (1) in 2014 AD to volume (12) No. (3) in 2017 


\section{Ml Macrothink}

CE The number of them is one (1) only.

- Mathematics education researches which was published in the book of the Fifth Conference on Mathematics Education and Learning, 2017, which belongs to the Saudi Society for Mathematical Sciences (Jisr) and its number (17).

The Analysis Card was prepared for the analysis of mathematics education research consists of three axes related to the analysis of the research methodology in terms of: determining the research methodology used, the sample (its type, method of selection), tools (number, type, source), and two axes related to the analysis of the research topic in terms of: type of education, the targeted academic stage, and the overall goal of research. To ensure the suitability of the card, it was presented to five specialists in the field of educational research and expressed their agreement to the suitability of the axes of the analysis card for the purpose of the study. The data were processed statistically by frequency and percentage.

\section{Findings and Discussion}

\subsection{The First Question}

What is the reality of mathematics education research in the Kingdom of Saudi Arabia during the period (2014-2018) in terms of: research methodology, sampling (type, method of selection), tools (number, type, source)?

To answer this question, the methodology of mathematics education research conducted during the period 2014-2018 was analyzed and the methodology used in scientific research was determined in the following types: experimental, descriptive, historical, case study, mixed, qualitative, content analysis, And percentages of research on mathematics education. The results were as shown in the following Table 1.

Table 1. The reality of mathematics education research in the Kingdom of Saudi Arabia during the period (2014-2018) in terms of research methodology

\begin{tabular}{|l|l|l|}
\hline Study method & Repetitions & Percentage \\
\hline Experimental & 21 & $40 \%$ \\
\hline Descriptive & 26 & $50 \%$ \\
\hline Historical & 0 & $0 \%$ \\
\hline Case study & 0 & $0 \%$ \\
\hline Mixed & 0 & $0 \%$ \\
\hline qualitative & 1 & $2 \%$ \\
\hline Content Analysis & 3 & $6 \%$ \\
\hline Other & 1 & $2 \%$ \\
\hline Total & 52 & $100 \%$ \\
\hline
\end{tabular}




\section{Macrothink $\Delta$ Institute ${ }^{\text {tm }}$}

The highest percentage of the descriptive approach was the descriptive research $50 \%$ of the mathematics education research during the period (2018-2018). The experimental research rate was $40 \%$. The rest of the research methods included qualitative analysis, $10 \%$ of the total mathematics education research during the period (2014-2018).

In analyzing the samples in mathematics education research during the period (2014-2018) in terms of type and method of selection, the results were as follows:

Table 2. The reality of mathematics education research in the Kingdom of Saudi Arabia during the period (2014-2018) in terms of type of research sample

\begin{tabular}{|l|l|l|}
\hline Study sample & Repetitions & Percentage \\
\hline Faculty members & 2 & $4 \%$ \\
\hline Educational supervisors & 2 & $4 \%$ \\
\hline Teachers & 17 & $31 \%$ \\
\hline Pre-service teachers & 1 & $2 \%$ \\
\hline Students & 26 & $48 \%$ \\
\hline Special class of students & 1 & $2 \%$ \\
\hline Books and study documents & 5 & $9 \%$ \\
\hline Parents & 0 & $0 \%$ \\
\hline Research and scientific studies & 0 & $0 \%$ \\
\hline Others & 0 & $0 \%$ \\
\hline
\end{tabular}

The research focused on the students as a sample. The percentage of research applied to the students was $48 \%$, followed by the teachers with $31 \%$. While the lowest proportion was in research dealing with books, study documents, private student groups, educational supervisors, faculty members, and pre-service teachers.

In terms of sample selection, the results were as follows: 
Table 3. The reality of mathematics education research in the Kingdom of Saudi Arabia during the period (2014-2018) in terms of sample selection

\begin{tabular}{|l|l|l|}
\hline Method of sample selection & Repetitions & Percentage \\
\hline Simple random & 24 & $47 \%$ \\
\hline Intentional & 19 & $37 \%$ \\
\hline Cluster & 5 & $10 \%$ \\
\hline Strict & 0 & $0 \%$ \\
\hline Regularly & 0 & $0 \%$ \\
\hline Class & 3 & $6 \%$ \\
\hline Sample of chance & 0 & $0 \%$ \\
\hline Others & 0 & $0 \%$ \\
\hline
\end{tabular}

In the analysis of the data in Table 3, most of the mathematics education research was chosen by simple random sampling method $47 \%$, which is about half of the study sample. The sample was then chosen in a deliberate manner $37 \%$, Cluster $10 \%$ of the study sample.

The data collection tools used by mathematics education research were analyzed during the period (2014-2018), and were addressed in three aspects (number, type, and source). The results were as follows:

Table 4. The reality of mathematics education research in the Kingdom of Saudi Arabia during the period (2014-2018) in terms of the number of data collection tools

\begin{tabular}{|l|l|l|}
\hline No of tools & Repetitions & Percentage \\
\hline One tool & 30 & $59 \%$ \\
\hline More than one tool & 21 & $41 \%$ \\
\hline
\end{tabular}


Table 5. The Reality of mathematics education research in the Kingdom of Saudi Arabia during the period (2014-2018) in terms of type of data collection tools

\begin{tabular}{|l|l|l|}
\hline Type of tool & Repetitions & Percentage \\
\hline A questionnaire & 8 & $11 \%$ \\
\hline Interview & 4 & $6 \%$ \\
\hline Scale & 8 & $11 \%$ \\
\hline Content analysis card & 7 & $10 \%$ \\
\hline Note & 8 & $11 \%$ \\
\hline Test & 25 & $35 \%$ \\
\hline Other & 11 & $15 \%$ \\
\hline
\end{tabular}

Table 6. The reality of mathematics education research in the Kingdom of Saudi Arabia during the period (2014-2018) in terms of source data collection tools

\begin{tabular}{|l|l|l|}
\hline Source of tool & Repetitions & Percentage \\
\hline Researcher design & 46 & $87 \%$ \\
\hline Ready & 6 & $11 \%$ \\
\hline Development of the researcher & 1 & $2 \%$ \\
\hline
\end{tabular}

In terms of the number of tools used, in terms of the data in Table 5, most of the research was based on one tool, although the percentages were relatively close. The percentage of research on mathematics teaching using one tool reached $59 \%$, while the research used more than one tool $41 \%$. In terms of the type of tools used, the most commonly used is the test $35 \%$, followed by (other), which is represented in training programs $15 \%$. The rates of observation, measurements and questionnaire are equal to $11 \%$ of mathematics education research tools during the period (2014-2018). And finally, the analysis cards $10 \%$ and interview $6 \%$. In terms of the source of the tool used, the results of the analysis of the source of the tools in which data were collected in mathematics education research during the period from (2014-2018). The percentage of tools that were designed by researchers $87 \%$ is the largest proportion. This is followed by ready tools that have been used in previous studies, which amounted to $11 \%$, and the lowest percentage of tools developed by the researchers in only one research $2 \%$.

\subsection{The Second Question}

What are the objective orientations of mathematics education research in the Kingdom of Saudi Arabia during the period (2014-2018)?

To answer the second sub-question of the study, Researches of education mathematics in Saudi Arabia during the period (2014-2018) was analyzed in the axis of the type of education 
and the stage of study. The overall objective of the study was analyzed. The frequencies and percentages of the categories included in the analysis card were calculated and the results were as follows:

Table 7. Trends in mathematics education research in the Kingdom of Saudi Arabia during the period (2014-2018) in terms of type of education

\begin{tabular}{|l|l|l|}
\hline Type of education & Repetition & Percentage \\
\hline high education & 6 & $12 \%$ \\
\hline general education & 43 & $83 \%$ \\
\hline Special education & 1 & $2 \%$ \\
\hline Technical & 0 & $0 \%$ \\
\hline Senior Education & 0 & $0 \%$ \\
\hline Other & 2 & $4 \%$ \\
\hline
\end{tabular}

Researches of education mathematics in Saudi Arabia during the period (2014-2018) focused on general education. The percentage of research in general education $83 \%$ was very high, followed by studies in higher education $12 \%$, Then special education by $2 \%$, then (other), which is in the study of international curricula by $4 \%$, and did not address the research technical and technical education and adult education.

With regard to the school stage, the results were as follows:

Table 8. Trends of mathematics education research in the Kingdom of Saudi Arabia during the period (2014-2018) in terms of the school stage

\begin{tabular}{|l|l|l|}
\hline Educational level & Repetition & Percentage \\
\hline Pre-primary & 0 & $0 \%$ \\
\hline Primary stage & 24 & $47 \%$ \\
\hline Middle school & 14 & $27 \%$ \\
\hline High school & 7 & $14 \%$ \\
\hline University stage & 6 & $12 \%$ \\
\hline Graduate Studies & 0 & $0 \%$ \\
\hline
\end{tabular}

From Table 8 it is clear that the primary stage is the most repetitive stage, with $47 \%$, intermediate $27 \%$, secondary $14 \%$ and undergraduate $12 \%$. Research on pre-primary 
(kindergarten) and postgraduate studies has been lacking. The researcher believes that the reason that the primary stage is the most important target groups of research may be due to the basis for the subsequent stages. While the lack of interest in the kindergarten stage may be due to the fact that it is not considered formal and compulsory education in the Kingdom, except for the lack of governmental educational institutions that are interested in this stage.

In analyzing the trends of mathematics education research in the Kingdom of Saudi Arabia during the period (2014-2018) in terms of the overall objective of the research, the results were as follows:

Table 9. Trends of mathematics education research in the Kingdom of Saudi Arabia during the period (2014-2018) in terms of the overall objective of the research

\begin{tabular}{|c|c|c|}
\hline The goal of the research & Repetition & Percentage \\
\hline Survey and study the reality of educational problems and phenomena & 9 & $17 \%$ \\
\hline $\begin{array}{l}\text { Measuring the impact or effectiveness of educational programs, methods, } \\
\text { strategies and teaching approaches }\end{array}$ & 6 & $11 \%$ \\
\hline Measuring the impact and effectiveness of teaching methods and techniques & 15 & $28 \%$ \\
\hline Tracking educational problems and phenomena over time & 0 & $0 \%$ \\
\hline Evaluation and evaluation of performance and educational practices & 3 & $6 \%$ \\
\hline Analysis of study documents (evaluation-implementation-development-design) & 6 & $11 \%$ \\
\hline Types of knowledge and mathematical processes & 0 & $0 \%$ \\
\hline Branches of mathematics content & 0 & $0 \%$ \\
\hline Compare educational experiences or practices & 0 & $0 \%$ \\
\hline $\begin{array}{l}\text { Predicting and anticipating the educational future, and research orientations } \\
\text { and post-analysis }\end{array}$ & 0 & $0 \%$ \\
\hline Detection of relationships and causes of behavior and educational phenomena & 1 & $2 \%$ \\
\hline Develop and improve some elements of the educational process & 0 & $0 \%$ \\
\hline Planning some elements of the educational process & 0 & $0 \%$ \\
\hline Proposing educational programs, models or strategies & 1 & $2 \%$ \\
\hline $\begin{array}{l}\text { Teacher (development of professional performance-directions-prepared } \\
\text { before service) }\end{array}$ & 8 & $15 \%$ \\
\hline Developing and measuring the cognitive aspects of the learner & 3 & $6 \%$ \\
\hline Development and measurement of the emotional aspects of the learner & 0 & $0 \%$ \\
\hline Development and measurement of the technical aspects of the learner & 2 & $4 \%$ \\
\hline Other & 0 & $0 \%$ \\
\hline
\end{tabular}




\section{MInstitute Macrothink $_{\text {Int }}^{\text {Intis }}$}

Table 9 shows the diversity of research objectives that mathematics education research sought during the period (2014-2018) to achieve, to include only 10 categories of categories included in the analysis card. The details are as follows:

- The goal of $28 \%$ of mathematics education research during the period (2014-2018) is to measure the impact and effectiveness of educational means and techniques, which is the most common goal. From the point of view of the researcher that this is due to the technological and technological development of the current era, where researchers seek to integrate technology in the educational process to keep pace with this development. This is in line with Al-Balawi's (2010) study that education techniques are the most independent variables studied.

- While $17 \%$ of the research on mathematics education during the period (2014-2018) to survey and study the reality of problems and phenomena of education, and the researcher's support that most of the master's thesis, which was the largest segment of the sample of this study interested in this type of studies. This supports the high proportion of the descriptive approach of these studies.

- In addition, $15 \%$ of the mathematics education research during the period (2014-2018) aimed at the teacher (developing his professional performance, orientation, preparation). The percentage of research aimed at measuring the impact or effectiveness of educational programs, methods, strategies and teaching approaches $11 \%$ was measured in both studies. While the five goals (development and measurement of the cognitive aspects of the learner, development and measurement of the skills of the learner, the proposal of programs or models or educational strategies, the detection of relations and causes of behavior and educational phenomena, assessment and evaluation of performance and educational practices) on low rates ranging between $2 \%$ and $6 \%$. While eight goals were not addressed in mathematics education research during the period (2014-2018). From the perspective of the researcher that the focus on certain goals and not to include all aspects of mathematics education research is a defect and a gap must be filled in terms of diversity in the directions of scientific research, and this is what this study attempts to address the development of a proposed vision for a research map that directs the future research in the field of mathematics education.

\subsection{The Third Question}

To answer the third question:

What is the proposed scenario for a research map that will guide future research in the field of mathematics education in view of the foundations of Vision 2030?

In this study, the researcher presented a suggested scenario for a research map that will guide the future research in the field of mathematics education in the view of the foundations of Vision 2030. The aim of this study is to identify the dimensions and areas of research in mathematics education. And addressed topics that contribute to the proposed solutions to some issues and problems in the teaching of mathematics. 
Target groups of the research map:

This research map may benefit the gathering of practitioners for the task of scientific research in the teaching of mathematics, especially:

- Graduate students

- Faculty members

- Teachers and educational supervisors

- Centers of Research Excellence.

The proposed scenario is as follows:

The proposed vision of a research map that guides the future research in the field of mathematics education in the view of the foundations of Vision 2030.

Key to dealing with the proposed research map:

- Determine the dimension that the researcher wishes to address.

- Identifying the focus of the vision and the goals of the national transformation programs 2020 (see Appendix B Table 1: Linking the objectives of the national transformation programs 2020 with the axes of vision).

- Specify the research field (if not within the proposed field, it can be added to the "Other" field).

- Identify the dimension that may interact with the main dimension. And determine the search area for this dimension (by placing the domain number within the table).

- Identify the target vocabulary in the research (study sample, type of education, stage, research methodology, research tools) using the allocated tables and put the appropriate number in front of the main dimension chosen in step (1).

- Generate the research idea by intersecting the search field row with at least four columns, and then format the search title using these options as keywords.

\section{Conclusion}

The results of the present study indicate that the majority of mathematics education research in the Kingdom of Saudi Arabia was descriptive and experimental. The research sample was also focused on students, and on the method of simple random sampling. In terms of research tools, the majority of research relied on one tool from the researcher's design, and the tests were the most used. Research also focused on the primary stage in general education. The largest percentage of mathematics education research aimed to measure the impact and effectiveness of teaching aids and techniques. The research went out by setting a model for a research map that guides the course of future research in the field of mathematics education in the view of the pillars of Vision 2030 so that this vision aims to define the dimensions and areas of research in mathematics education that it is hoped will open the way for researchers 
to derive research ideas and address issues that contribute to providing Suggested solutions to some issues and problems in mathematics education.

\section{References:}

Ababneh, S. A. (2015). Contemporary educational planning theory and practice. Amman, Jordan: Dar Al Masirah for Publishing and Distribution.

Abdul Hay, R. A. (2006). Al-Wafaa Printing \& Publishing, Alexandria.

AL-Al-Balawi, A. S. (2010). Research priorities in mathematics education and learning in Saudi Arabia. Journal of Studies in Curriculum and Teaching Methods, 155, 90-142.

Al-Ama'i. (2018). Planning Guide Towards the Future. Arab Bureau of Education for the Gulf States.

Al-Astadh, M. H., \& Hajjar, R. H. (2005). Towards a Developmental Research Map in Academic Educational Research. Al-Aqsa University Journal (Human Sciences Series), 9(1), 245-273.

Al-Muatham, K. A. (2007). Trends of Research in Mathematics Education in Postgraduate Studies at the Universities of Saudi Arabia Analytical Study of Master and PhD Thesis (Unpublished PhD thesis, Faculty of Education, Umm Al-Qura University, Makkah).

Al-Muatham, K. A. (2013). The orientations of scientific production in the teaching of mathematics published in Gulf journals. Mathematics Education Journal, 16, 70-131.

Al-Salahi, S. M. (2017). Roles of scientific research in Saudi universities towards the transformation of society and knowledge economy in light of the requirements of the vision of the Kingdom 2030 (No. 1, pp. 299-320). Eighth Conference: Information institutions in the Kingdom of Saudi Arabia and their role in supporting the economy and knowledge society. Riyadh: Saudi Society for Libraries and Information.

Alshaya, F. S. (2007). Trends and Characteristics of Master Thesis in Scientific Education at King Saud University. Journal of Teacher Colleges, Educational Sciences, 7(2), 44-100.

Amer, T. A. R. (2007). Educational planning and school map. Cairo, Egypt: Zahraa Al Sharq Library.

Assaf, S. H. (2010). Introduction to research in behavioral sciences (No. 1). Riyadh: House of Zahra.

Azab, M. A. A. (2013). Suggested research map of the Department of Educational Assets. Educational and psychological studies. Journal of Faculty of Education Zagazig, 81, 61-89.

Ba'adi, H. (1989). Educational Research in the Kingdom of Saudi Arabia: Structure and Evaluation. Symposium on activating educational research conducted at the University of Emirates in cooperation with UNESCO.

Brophy, T. (1986). Teaching and learning mathematics: Where research should be done. Journal for Research in Mathematics Education, 17(5). https://doi.org/10.2307/749326 
Caliph, A. A. A. (2015). A development vision for the scientific research system in Saudi universities in the light of global competitiveness. Saudi Journal of Higher Education, 12, 11-49.

Center of Excellence Research in the Development of Science and Mathematics Education. (2009). Report on the "Priorities for Research in Science and Mathematics Education in Saudi Arabia” workshop. King Saud University, Riyadh.

Harb, M. K. (2013). Application of knowledge management in universities to achieve excellence in educational research, educational and psychological studies. Journal of Faculty of Education Zagazig, 79, 139-228.

Ibrahim, A. A., \& Abdul-Majid, M. M. (2006). An analytical study of trends in contemporary scientific education and its future fields. Journal of Scientific Education, 9(1), 1-54.

Ibrahim, N. Z. (1984). Trends in scientific research in the field of teaching mathematics in basic education. Conference on Mathematics in Basic Education, 21-25 September, Faculty of Education, El-Arish, Suez Canal University, Egypt.

Khalifa, A. S. K. (2002). Educational renewal in the study of mathematics education. Second Scientific Conference of the Egyptian Association of Mathematics Education (Research in Mathematics Education), 4-5 August 2002, Ain Shams University, Cairo.

Mahmoud, H. A. M. (1992). The priorities of educational research in the field of school administration "Field study" (No. 1, pp. 219-252). Conference of Educational Policies in the Arab World.

Mena, F. M. (2002). Proposed Theory of Educational Research in Mathematics Education. The Second Annual Scientific Conference of the Egyptian Society for Mathematics Education, Ain Shams University, Cairo.

Noah, M. A. (2015). A proposed research map on the origins of education in Saudi universities. Journal of the Association of Modern Education, 22, 215-271.

Sakka, E. A. (2015). The basics of educational planning. Amman, Jordan: Dar Al Masirah for Publishing and Distribution.

Salem, S. M. (2003). The extent of the contribution of the Master and PhD thesis submitted to Saudi universities in the service of comprehensive development issues. Saudi Journal of Higher Education, 1(1).

Sharnoubi, H. S. I. (2010). The effectiveness of using some e-learning strategies across the web and meta-knowledge strategies in the response of postgraduate students in the field of education technology: On the proposed research map in the field and the development of their e-research skills and beyond-knowledge thinking. Journal of Education, Al-Azhar University, 5(144), 13-154.

Vision of Saudi Arabia 2030. Retrieved from https://vision2030.gov.sa/download/file/fid/422 


\section{Appendix}

The proposed scenario for a research map that will guide future research in the field of mathematics education in the view of the foundations of Vision 2030

Table A1. Link the objectives of the national transformation programs 2020 with the axes of vision

\begin{tabular}{|c|c|c|}
\hline \multicolumn{2}{|l|}{ Vision axes } & National Transition Programs 2020 in the Ministry of Education \\
\hline \multirow{4}{*}{$\begin{array}{l}\text { 1) Ambitious } \\
\text { homeland }\end{array}$} & \multirow{3}{*}{$\begin{array}{l}\text { 1) Effective } \\
\text { governance }\end{array}$} & $\begin{array}{l}\text { 1) Strengthen the capacity of the education and training system to } \\
\text { meet the requirements of development and labor market needs. }\end{array}$ \\
\hline & & $\begin{array}{l}\text { 2) Strengthen the capacity of the education and training system to } \\
\text { meet the requirements of development and labor market needs. }\end{array}$ \\
\hline & & $\begin{array}{l}\text { 3) Diversify innovative financing sources and improve the } \\
\text { financial efficiency of the education sector }\end{array}$ \\
\hline & 2) Responsible citizen & $\begin{array}{l}\text { 4) Improve the recruitment, rehabilitation and development of } \\
\text { teachers. }\end{array}$ \\
\hline \multirow{3}{*}{$\begin{array}{l}\text { 2) A vital } \\
\text { society }\end{array}$} & 3) Firm values & 5) Promote values and skills for students. \\
\hline & \multirow{2}{*}{ 4) A rich environment } & $\begin{array}{l}\text { 6) Improve the educational environment that stimulates } \\
\text { creativity and innovation. }\end{array}$ \\
\hline & & $\begin{array}{l}\text { 7) Development of curricula and methods of education and } \\
\text { evaluation. }\end{array}$ \\
\hline \multirow{4}{*}{$\begin{array}{l}\text { 3) A prosperous } \\
\text { economy }\end{array}$} & \multirow{3}{*}{$\begin{array}{l}\text { 5) a fruitful } \\
\text { opportunity }\end{array}$} & $\begin{array}{l}\text { 8) Diversify innovative financing sources Improve financial } \\
\text { efficiency of the education sector. }\end{array}$ \\
\hline & & 9) Provide educational services for all students \\
\hline & & $\begin{array}{l}\text { 10) Strengthen the capacity of the education and training system } \\
\text { to meet the requirements of development and labor market needs. }\end{array}$ \\
\hline & $\begin{array}{l}\text { 6) Competitive } \\
\text { attractiveness }\end{array}$ & 11) Raising private sector participation in education and training. \\
\hline
\end{tabular}


Table A2. Research sample

\begin{tabular}{|c|c|c|}
\hline & Students & \multirow{9}{*}{$\begin{array}{l}\text { a) Males } \\
\text { b) Females } \\
\text { c) both of them }\end{array}$} \\
\hline 2) & Teachers & \\
\hline 3) & Supervisors & \\
\hline 4) & school's director & \\
\hline 5) & parents & \\
\hline 6) & faculty of school & \\
\hline 7) & Student Teacher & \\
\hline 8) & Documents & \\
\hline & Others & \\
\hline
\end{tabular}

Table A3. Type of education and school stage

\begin{tabular}{|l|l|}
\hline Type of education & Educational level \\
\hline 1) general education & 1) Kindergarten \\
\hline 2) University education & 2) Preliminary Preparatory \\
\hline 3) special education & 3) High elementary \\
\hline 4) Technical & 4) intermediate \\
\hline 5) Senior Education & 5) Secondary \\
\hline 6) Other & 6) Diploma \\
\hline & 7) Bachelor \\
\hline & 8) High graduate \\
\hline
\end{tabular}

Table A4. Research tools

\begin{tabular}{|c|c|c|}
\hline No. & Type of tool & Source \\
\hline \multirow{7}{*}{$\begin{array}{l}\text { i) One tool } \\
\text { ii) More than tool }\end{array}$} & 1) Test & \multirow{7}{*}{$\begin{array}{l}\text { a) Researcher design } \\
\text { b) Researcher development } \\
\text { c) Ready made }\end{array}$} \\
\hline & 2) Questionnaire & \\
\hline & 3) Scale & \\
\hline & 4) Analysis card & \\
\hline & 5) Note & \\
\hline & 6) Interview & \\
\hline & 7) other & \\
\hline
\end{tabular}


Table A5. The research methodology used

\begin{tabular}{|ll|}
\hline 1) & Experimental \\
\hline 2) & Semi Experimental \\
\hline 3) & Descriptive \\
\hline 4) & Historical \\
\hline 5) & Qualitative \\
\hline 6) & Other \\
\hline
\end{tabular}

Table A6. The branches of mathematical content and its mathematical processes

\begin{tabular}{|c|c|c|c|c|c|}
\hline \multicolumn{2}{|c|}{ Mathematical content } & \multicolumn{2}{|c|}{ Mathematical knowledge } & \multicolumn{2}{|c|}{ Mathematical operations } \\
\hline 1) & Numbers and processes & 1) & Mathematical issues & 1) & Solve the mathematical problem \\
\hline 2) & Geometry & 2) & Concepts & 2) & inference \\
\hline & Algebra & 3) & Algorithms and skills & 3) & Mathematical Communication \\
\hline 4) & Measurement & 4) & Principles and generalizations & 4) & Mathematical interdependence \\
\hline 5) & Statistics and Probability & 5) & General & 5) & Mathematical Representation \\
\hline 6) & General & & & 6) & General \\
\hline
\end{tabular}




\section{MInstitute Macrothink $_{\text {Int }}$}

Journal of Educational Issues

ISSN 2377-2263

2020, Vol. 6, No. 1

Table A7. Proposed future map of mathematics education research (dimension of teacher)

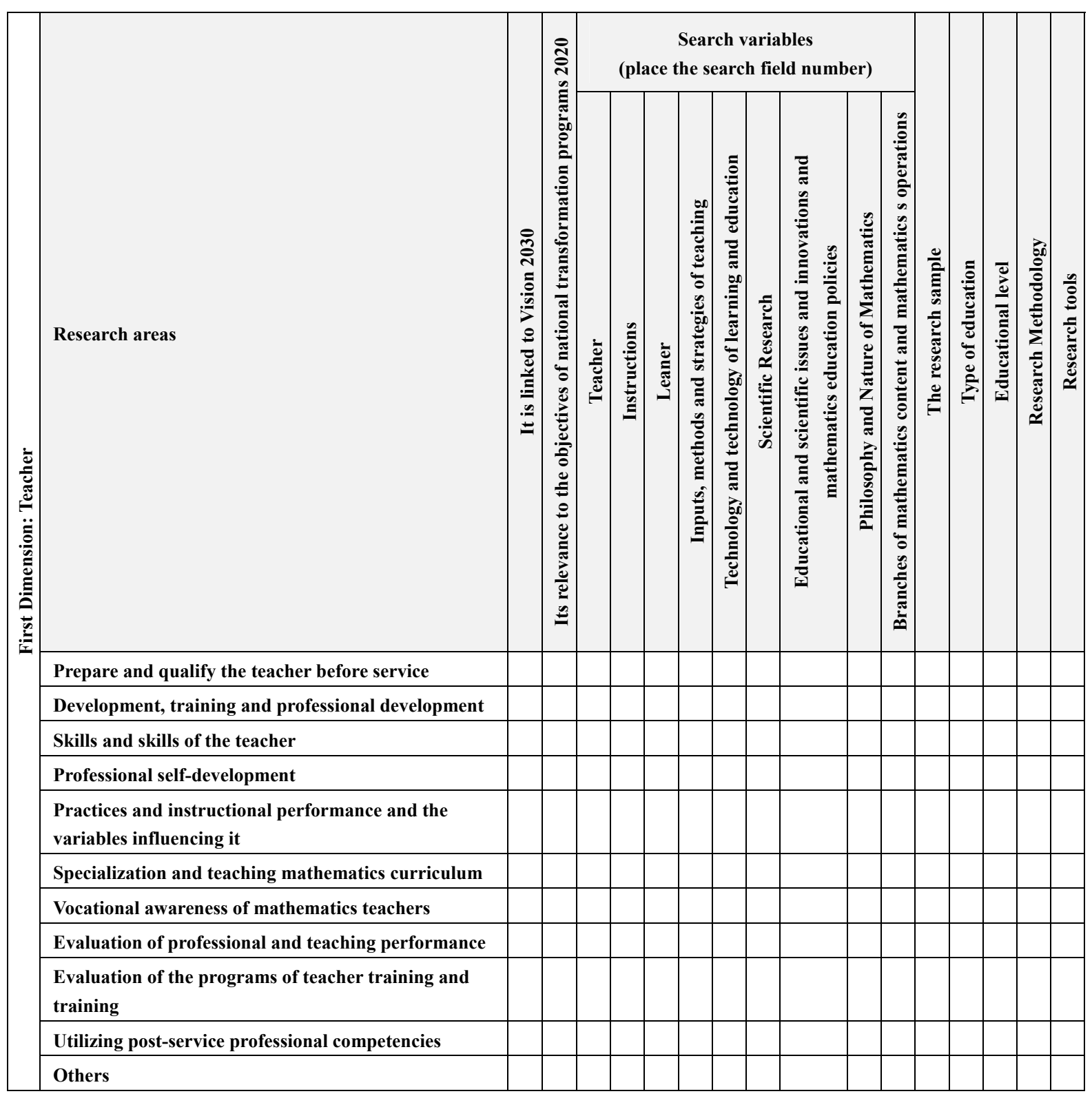




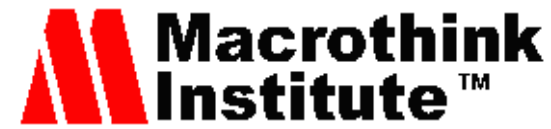

Journal of Educational Issues

ISSN 2377-2263

2020, Vol. 6, No. 1

Table A8. Proposed future map of mathematics education research (dimension of curriculum)

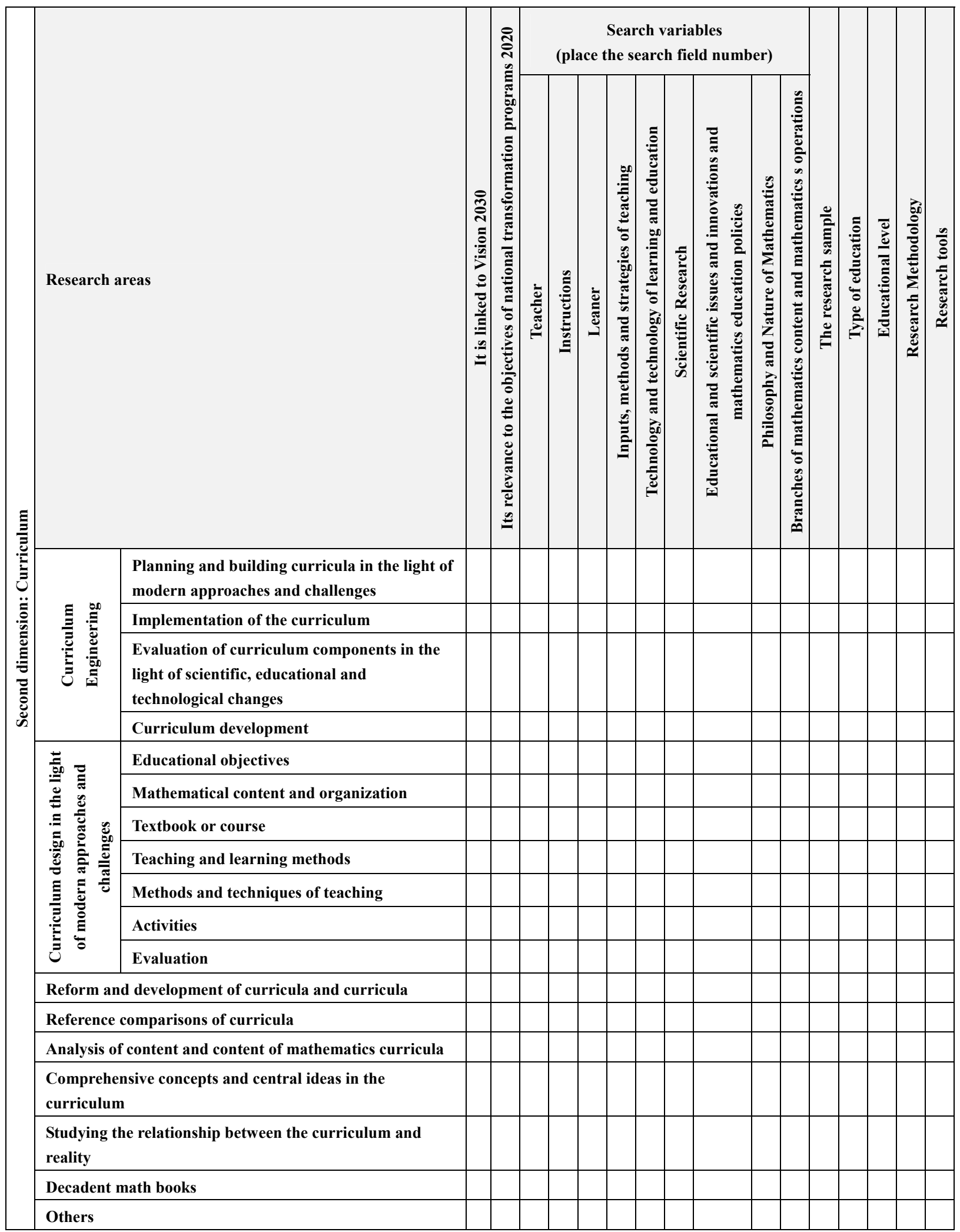


Table A9. Proposed future map of mathematics education research (dimension of learner)

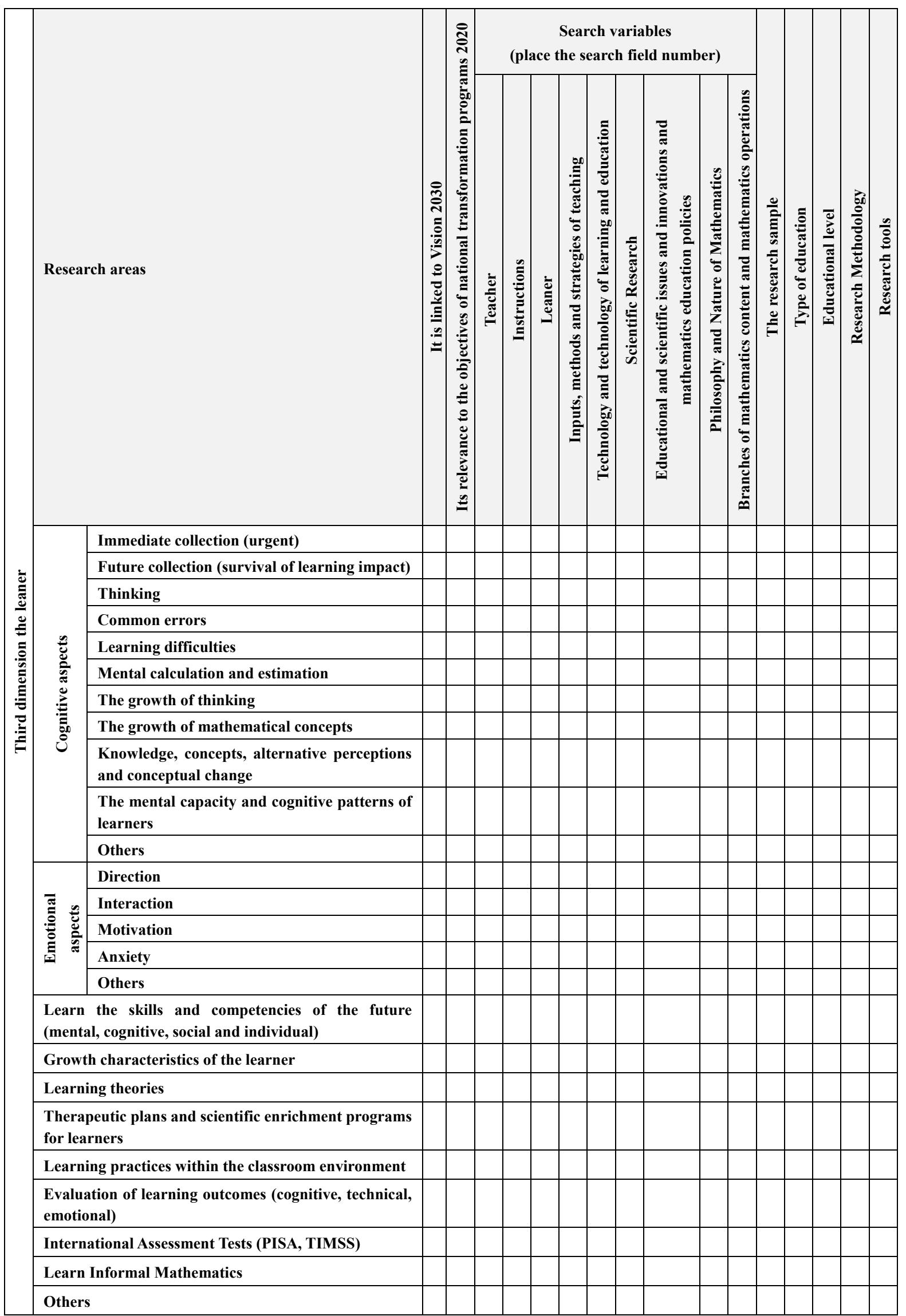


Table A10. Proposed future map of mathematics education research (dimension of teaching approaches, methods and strategies)

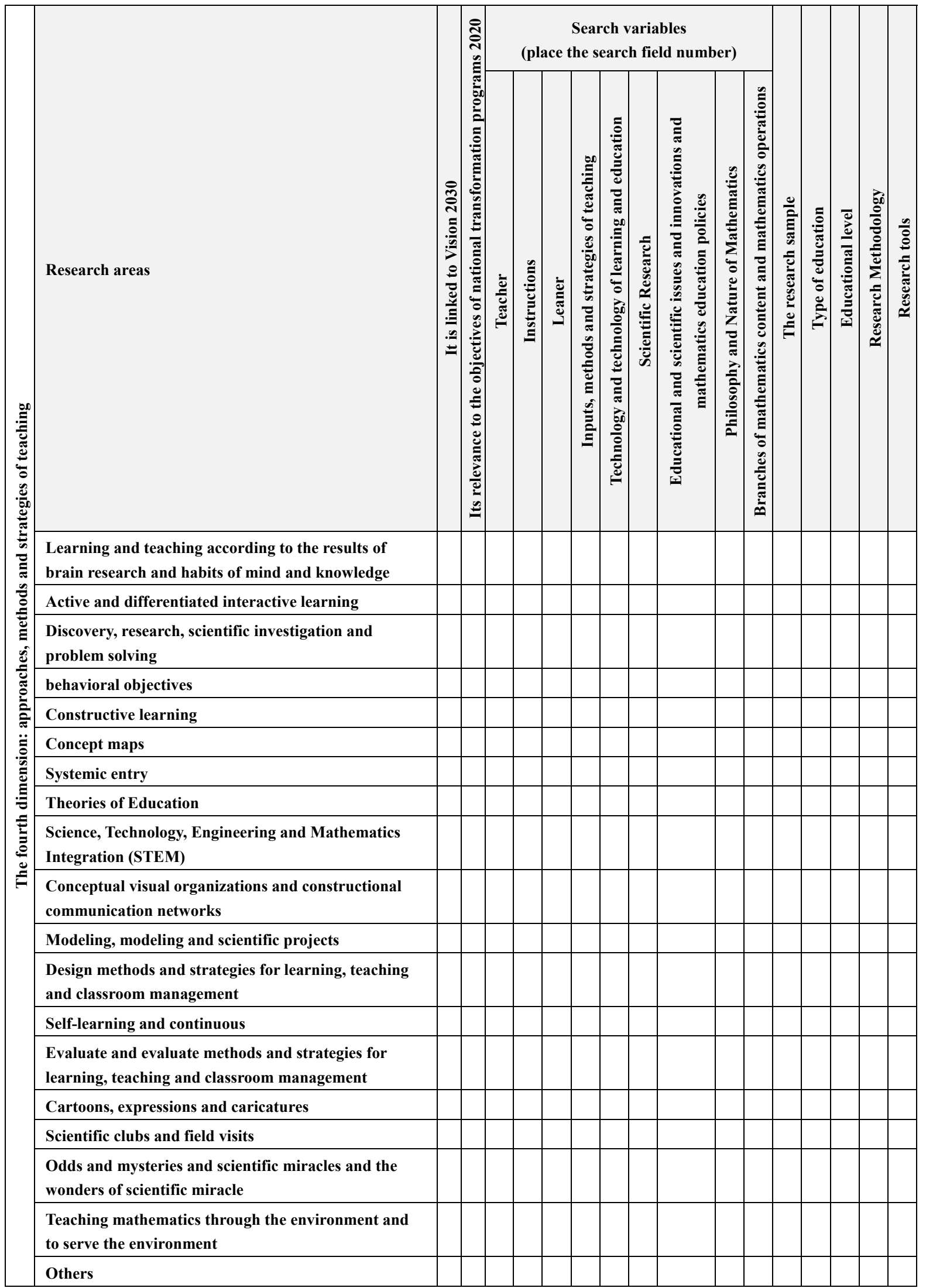




\section{MInstitute ${ }_{\text {Macrothink }}^{\text {Mack }}$}

Journal of Educational Issues

ISSN 2377-2263

2020, Vol. 6, No. 1

Table A11. Proposed future map of mathematics education research (dimension of learning and learning technology and technology)

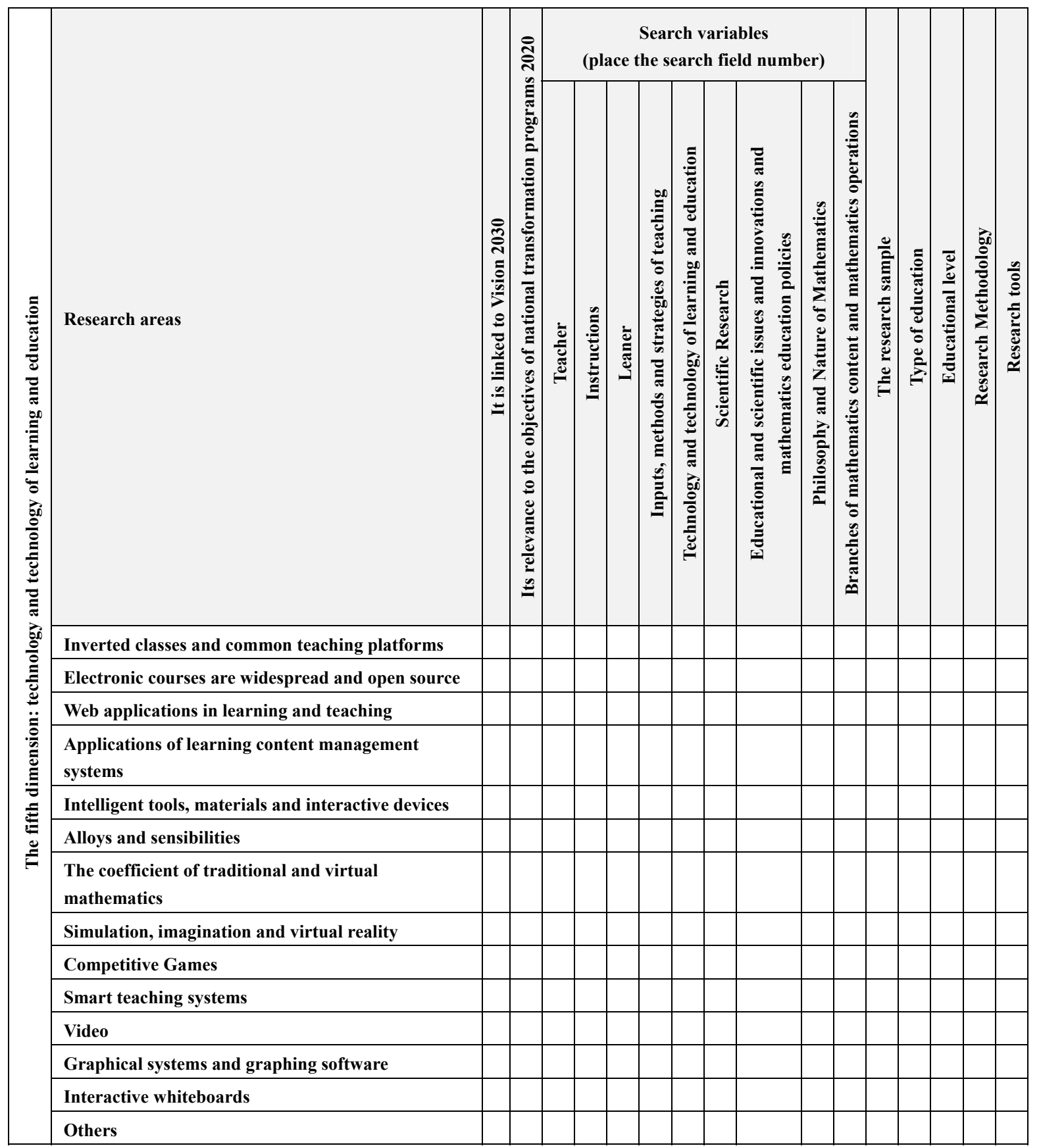




\section{MInstitute Macrothink $^{m}$}

Journal of Educational Issues

ISSN 2377-2263

2020, Vol. 6, No. 1

Table A12. Proposed future map of mathematics education research (dimension of scientific research)

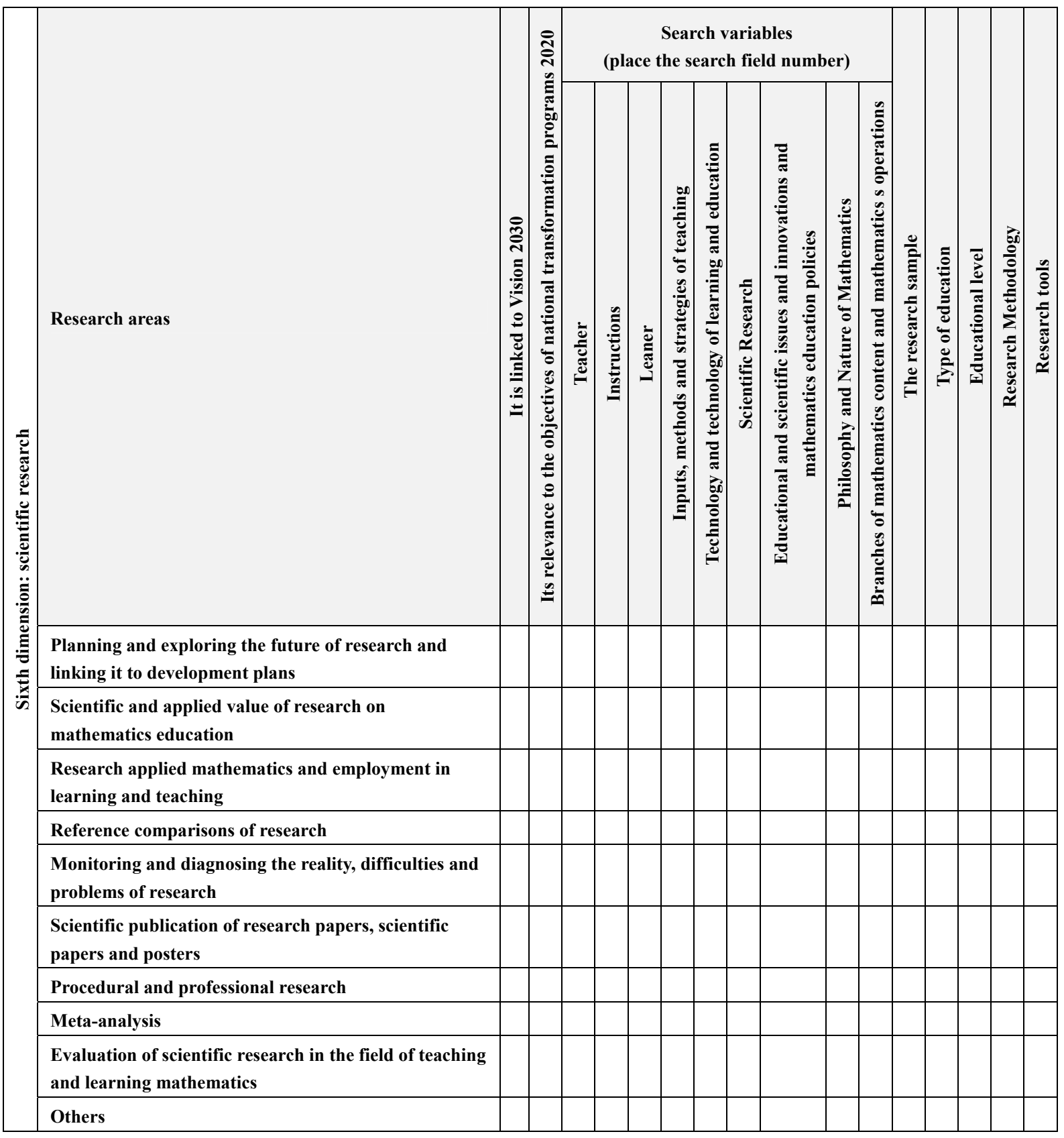


Table A13. Proposed future map of mathematics education research (dimension educational and scientific issues and innovations and mathematics education policies)

\begin{tabular}{|c|c|c|c|c|c|c|c|c|c|c|c|c|c|c|c|c|c|}
\hline & & & & & & place & & esea & val & iables & nber & & & & & & \\
\hline 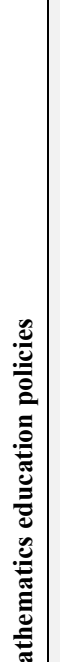 & Research areas & 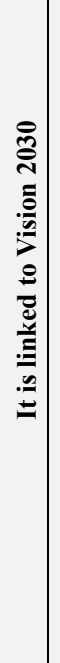 & 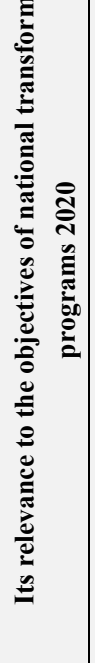 & 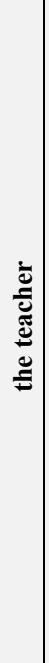 & | & 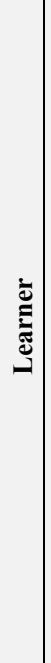 & 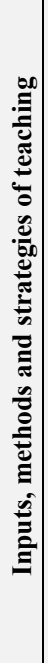 & 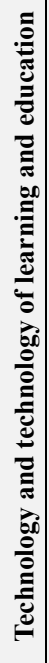 & 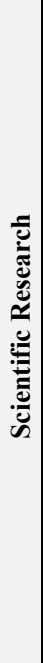 & 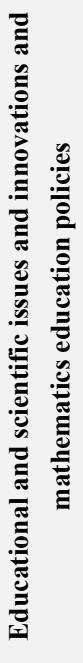 & 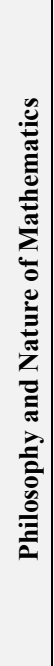 & 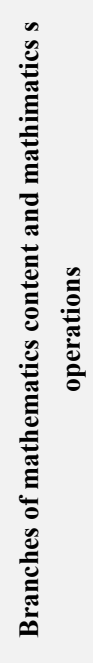 & 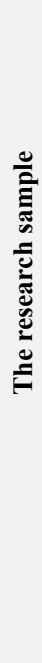 & 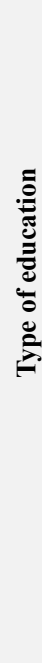 & 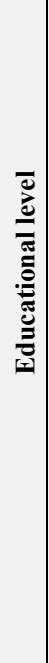 & 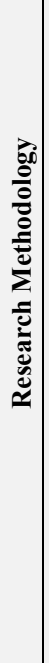 & 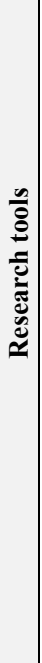 \\
\hline 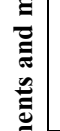 & $\begin{array}{l}\text { Transition towards knowledge societies and } \\
\text { the knowledge economy towards knowledge } \\
\text { societies and the knowledge economy }\end{array}$ & & & & & & & & & & & & & & & & \\
\hline$\frac{e^{2}}{\frac{0}{0}}$ & $\begin{array}{l}\text { Craft, community professions and future } \\
\text { labor market needs }\end{array}$ & & & & & & & & & & & & & & & & \\
\hline כ & Invention and innovation & & & & & & & & & & & & & & & & \\
\hline$\tilde{z}$ & Artificial Intelligence & & & & & & & & & & & & & & & & \\
\hline 离 & $\begin{array}{l}\text { Interrelationship between science and } \\
\text { technology, the environment, society and the } \\
\text { profession of the future }\end{array}$ & & & & & & & & & & & & & & & & \\
\hline 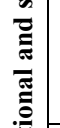 & $\begin{array}{l}\text { Planning and developing programs and } \\
\text { projects in light of global and contemporary } \\
\text { trends }\end{array}$ & & & & & & & & & & & & & & & & \\
\hline 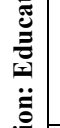 & $\begin{array}{l}\text { Evaluate the efficiency and effectiveness of the } \\
\text { mathematics education system (inputs, } \\
\text { outputs, processes) }\end{array}$ & & & & & & & & & & & & & & & & \\
\hline 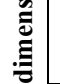 & $\begin{array}{l}\text { Applications of scientific knowledge in life } \\
\text { situations }\end{array}$ & & & & & & & & & & & & & & & & \\
\hline 吾 & $\begin{array}{l}\text { Performance criteria and indicators for } \\
\text { elements of the mathematics education system }\end{array}$ & & & & & & & & & & & & & & & & \\
\hline & $\begin{array}{l}\text { Practical applications of educational theories } \\
\text { in teaching mathematics }\end{array}$ & & & & & & & & & & & & & & & & \\
\hline & $\begin{array}{l}\text { The unity and dynamics of science and } \\
\text { knowledge integration. }\end{array}$ & & & & & & & & & & & & & & & & \\
\hline & $\begin{array}{l}\text { Effective partnership of the public, private } \\
\text { and community sectors }\end{array}$ & & & & & & & & & & & & & & & & \\
\hline & $\begin{array}{l}\text { Investing and financing mathematics } \\
\text { education }\end{array}$ & & & & & & & & & & & & & & & & \\
\hline & $\begin{array}{l}\text { Culture and scientific and technical } \\
\text { enlightenment }\end{array}$ & & & & & & & & & & & & & & & & \\
\hline
\end{tabular}


Quality and academic and academic accreditation

Purposes and objectives of scientific education and mathematics education

Internationalization of mathematics education

Values and ethics associated with science,

religion, society and occupation

The progress and achievements of scientists

and innovators and the construction of

scientific personality

Others

Table A14. Proposed future map of mathematics education research (dimension the philosophy and nature of mathematics)

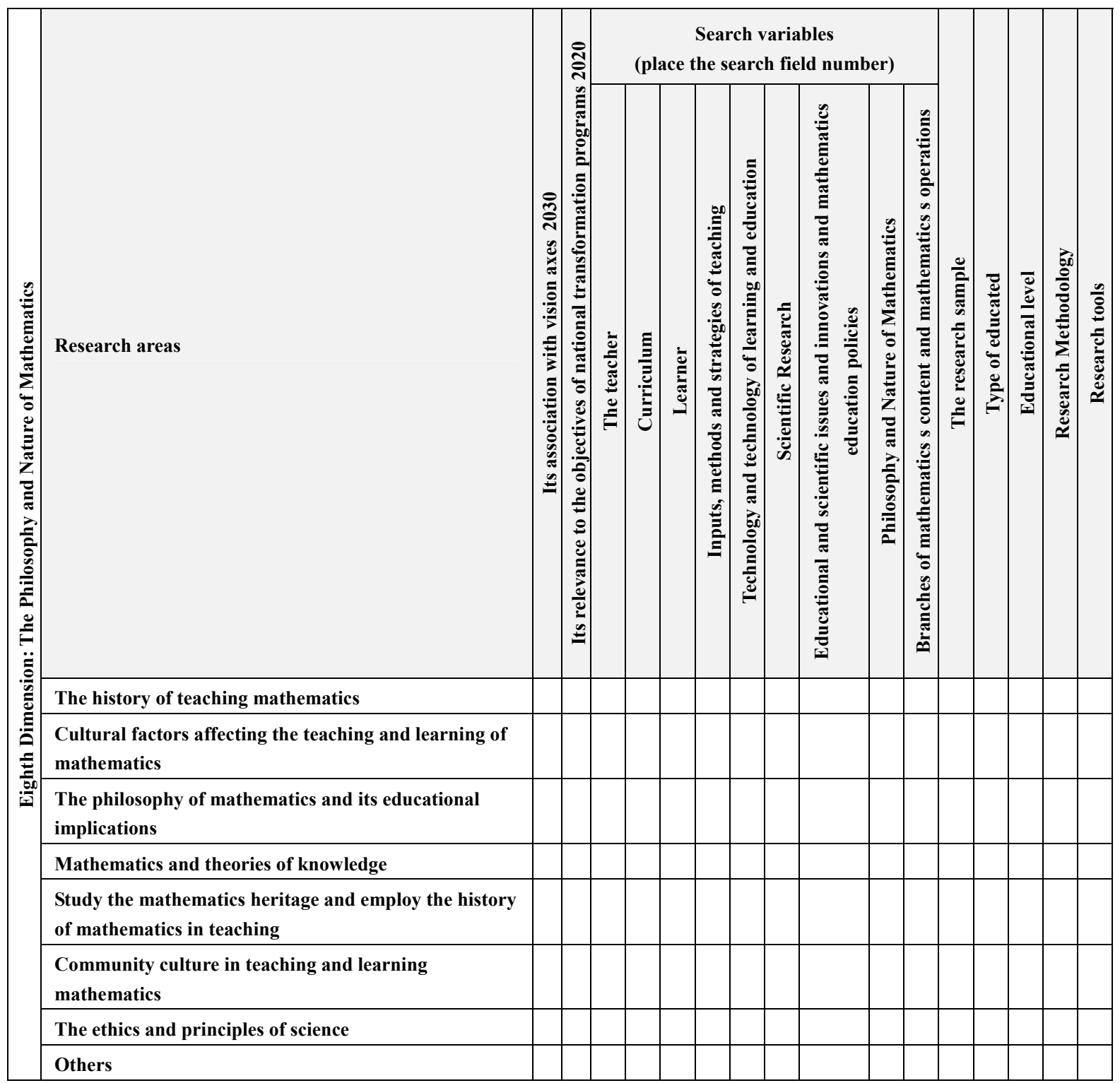




\section{Copyright Disclaimer}

Copyright for this article is retained by the author(s), with first publication rights granted to the journal.

This is an open-access article distributed under the terms and conditions of the Creative Commons Attribution license (http://creativecommons.org/licenses/by/3.0/). 